\section{Four Patients with COVID-19 and Tuberculosis, Singapore, April-May 2020}

\author{
Sai Meng Tham, Wei Yang Lim, Chun Kiat Lee, \\ Jerold Loh, Arthi Premkumar, Benedict Yan, \\ Adrian Kee, Louis Chai, Paul Anantharajah Tambyah, \\ Gabriel Yan
}

Author affiliation: National University Health System, Singapore

DOI: https://doi.org/10.3201/eid2611.202752

Coronavirus disease (COVID-19) and tuberculosis (TB) developed in 4 foreign workers living in dormitories in Singapore during April-May 2020. Clinical manifestations and atypical radiographic features of COVID-19 led to the diagnosis of TB through positive interferon-gamma release assay and culture results. During the COVID-19 pandemic, TB should not be overlooked.

$\Lambda$ $s$ the world focuses on the coronavirus disease (COVID-19) pandemic, caution must be taken to not overlook tuberculosis (TB). COVID-19 was first diagnosed in Singapore in January 2020, after cases were imported from Wuhan, China. Subsequent sustained community transmission of the virus followed a wave of imported cases from local residents returning from abroad (1). The outbreak in Singapore is being driven by spread within migrant worker dormitories. As of June 28, 2020, Singapore reported 43,459 confirmed cases of COVID-19, of which 41,010 were in dormitory residents (1). TB is endemic to Singapore; annual incidence rate is $\gg 40$ cases $/ 100,000$ population (2), and a large proportion of cases are in nonpermanent residents.

We describe migrant workers in Singapore dormitories who were co-infected with severe acute respiratory syndrome virus 2 (SARS-CoV-2) and $M y$ cobacterium tuberculosis. For all 4 patients, TB was diagnosed by positive interferon-gamma release assay (IGRA) (QIAGEN, https://www.qiagen.com); M. tuberculosis was isolated from pleural fluid culture from patient 4 only (Table).

Patient 1 was a 32-year-old man from India with a 2-day history of fever and cough. He was positive for SARS-CoV-2 by reverse transcription PCR (RTPCR) of a nasopharyngeal swab sample. Radiographs showed bilateral cavitary lung lesions (Figure 1, panel A). Sputum samples were smear negative and culture negative for acid-fast bacilli (AFB) and negative by molecular testing for $M$. tuberculosis nucleic acids (Cepheid Xpert MTB/RIF, https://www.cepheid.com).
The IGRA for TB result was positive. In consideration of the clinical manifestations and risk factors, anti-TB therapy (ATT) was started, and interval radiographic imaging showed resolution.

Patient 2 was a 33-year-old man from India with an 8-day history of fever and cough and a 1-month history of weight loss $(3 \mathrm{~kg})$. He was positive for SARS-CoV-2 by RT-PCR of a nasopharyngeal swab sample. Radiographs showed a right-sided pleural effusion (Figure 1, panel B). Pleural fluid analysis revealed a lymphocytic exudative effusion with an adenosine deaminase (ADA) level of $130 \mathrm{U} / \mathrm{L}$ (reference range $<40 \mathrm{U} / \mathrm{L}$ ), but the fluid was negative for SARSCoV-2 by RT-PCR. Sputum and pleural fluid were smear negative for AFB and $M$. tuberculosis nucleic acid negative by molecular testing; culture results are pending. IGRA was positive for TB, and ATT was started with subsequent clinical improvement.

Patient 3 was a 22-year old man from India with a 10-day history of fever and cough (associated with exertional dyspnea) and pleuritic chest pain. He was positive for SARS-CoV-2 by RT-PCR of a nasopharyngeal swab sample. Radiographs showed a rightsided pleural effusion (Figure 1, panel C). Pleural fluid analysis revealed a lymphocytic exudative effusion with an ADA level of $112 \mathrm{U} / \mathrm{L}$ and interleukin-6 (IL-6) level of $>1,000 \mathrm{pg} / \mathrm{mL}$, but the fluid was negative for SARS-CoV-2 by RT-PCR. Sputum and pleural fluid were smear negative for AFB and negative for M. tuberculosis nucleic acids by molecular testing; culture results are pending. IGRA was positive for TB and ATT was started; symptoms subsequently resolved.

Patient 4 was a 40 -year old man from Bangladesh with a 3-day history of fever and cough. He was positive for SARS-CoV-2 by RT-PCR from a nasopharyngeal swab sample. Radiographs showed a left-sided pleural effusion with bilateral consolidation (Figure 1 , panel D). Pleural fluid analysis revealed a lymphocytic exudative effusion with an ADA level of 62 U/L and an IL-6 level of $>1,000 \mathrm{pg} / \mathrm{mL}$, but the fluid was negative for SARS-CoV-2 by RT-PCR. Sputum and pleural fluid were smear negative for AFB and negative for $M$. tuberculosis nucleic acids by molecular testing, but the IGRA for TB was positive. ATT was started, and pleural fluid cultures were subsequently positive for $M$. tuberculosis.

All 4 patients were workers who resided in dormitories and had COVID-19 but atypical radiographic features; typical radiographic features for COVID-19 patients include ground-glass opacities, multifocal patchy consolidation, and peripheral interstitialchanges (3). Despite confirmed diagnoses of COVID-19, 
Table. Epidemiologic and clinical features for 4 patients with coronavirus disease and tuberculosis, Singapore*

\begin{tabular}{|c|c|c|c|c|c|c|c|c|}
\hline $\begin{array}{l}\mathrm{Pt} \\
\text { no. }\end{array}$ & $\begin{array}{l}\text { Age, y/sex, } \\
\text { nationality }\end{array}$ & $\begin{array}{c}\text { Initial } \\
\text { signs/sympto } \\
\mathrm{ms}\end{array}$ & Radiologic findings & $\begin{array}{l}\text { Pleural fluid } \\
\text { analysis }\end{array}$ & $\begin{array}{l}\text { Sputum } \\
\text { analysis }\end{array}$ & $\begin{array}{c}\text { Microbiological } \\
\text { findings }\end{array}$ & $\begin{array}{l}\text { IGRA } \\
\text { for TB }\end{array}$ & Outcome \\
\hline$\overline{1 \dagger}$ & 32/M, India & $\begin{array}{l}\text { Fever, } \\
\text { productive } \\
\text { cough }\end{array}$ & $\begin{array}{l}\text { CXR: right upper zone } \\
\text { and left lower zone } \\
\text { cavitary lesions; } \\
\text { chest CT: irregular } \\
\text { opacifications with } \\
\text { central cavitation }\end{array}$ & NA & $\begin{array}{l}\text { AFB smear } \\
\text { negative; } \\
\text { molecular } \\
\text { TB analysis } \\
\text { negative }\end{array}$ & $\begin{array}{c}\text { Sputum AFB } \\
\text { culture negative }\end{array}$ & + & $\begin{array}{c}\text { Symptoms } \\
\text { resolved; repeat } \\
\text { CXR after starting } \\
\text { ATT demonstrated } \\
\text { resolution of } \\
\text { cavitary lesions at } \\
2 \text { mo of treatment }\end{array}$ \\
\hline 2 & 33/M, India & $\begin{array}{c}\text { Fever, } \\
\text { nonproductive } \\
\text { cough; } 3-k g \\
\text { weight loss } \\
\text { over } 1 \text { mo }\end{array}$ & $\begin{array}{c}\text { CXR: right-sided } \\
\text { pleural effusion; } \\
\text { chest CT: loculated } \\
\text { right-sided effusion } \\
\text { with adjacent } \\
\text { collapse/consolidation }\end{array}$ & $\begin{array}{c}\text { Lymphocytic } \\
\text { exudative } \\
\text { effusion; } \\
\text { ADA } 130 \\
\text { U/L; } \\
\text { SARS-CoV- } \\
2 \text { PCR } \\
\text { negative }\end{array}$ & $\begin{array}{l}\text { AFB smear } \\
\text { negative; } \\
\text { molecular } \\
\text { TB analysis } \\
\text { negative }\end{array}$ & $\begin{array}{l}\text { Sputum and } \\
\text { pleural fluid } \\
\text { AFB cultures } \\
\text { pending }\end{array}$ & + & $\begin{array}{l}\text { Symptoms } \\
\text { resolved with } \\
\text { interval } \\
\text { improvement of } \\
\text { CXR }\end{array}$ \\
\hline $3 \dagger$ & 22/M, India & $\begin{array}{c}\text { Fever, } \\
\text { nonproductive } \\
\text { cough; } \\
\text { exertional } \\
\text { dyspnea, } \\
\text { pleuritic chest } \\
\text { pain }\end{array}$ & $\begin{array}{l}\text { CXR: right-sided } \\
\text { pleural effusion with } \\
\text { adjacent compressive } \\
\text { atelectasis }\end{array}$ & $\begin{array}{l}\text { Lymphocytic } \\
\text { exudative } \\
\text { effusion; } \\
\text { ADA } 112 \\
\text { U/L; } \\
\text { SARS-CoV- } \\
2 \text { PCR } \\
\text { negative }\end{array}$ & $\begin{array}{l}\text { AFB smear } \\
\text { negative; } \\
\text { molecular } \\
\text { TB analysis } \\
\text { negative }\end{array}$ & $\begin{array}{l}\text { Sputum and } \\
\text { pleural fluid } \\
\text { AFB cultures } \\
\text { pending }\end{array}$ & + & $\begin{array}{l}\text { Symptoms } \\
\text { resolved with } \\
\text { interval } \\
\text { improvement of } \\
\text { CXR }\end{array}$ \\
\hline 4 & $\begin{array}{c}\text { 40/M, } \\
\text { Bangladesh }\end{array}$ & $\begin{array}{c}\text { Fever, } \\
\text { productive } \\
\text { cough; } \\
\text { reduced effort } \\
\text { tolerance }\end{array}$ & $\begin{array}{l}\text { CXR: large left-sided } \\
\text { pleural effusion; } \\
\text { Chest CT: left-sided } \\
\text { pleural effusion, } \\
\text { bilateral patchy } \\
\text { consolidative changes } \\
\text { with ground-glass } \\
\text { opacities and } \\
\text { interlobular septal } \\
\text { thickening }\end{array}$ & $\begin{array}{l}\text { Lymphocytic } \\
\text { exudative } \\
\text { effusion; } \\
\text { ADA } 69 \mathrm{U} / \mathrm{L} ; \\
\text { SARS-CoV- } \\
2 \text { PCR } \\
\text { negative }\end{array}$ & $\begin{array}{l}\text { AFB smear } \\
\text { negative; } \\
\text { molecular } \\
\text { TB analysis } \\
\text { negative }\end{array}$ & $\begin{array}{c}\text { Sputum AFB } \\
\text { culture } \\
\text { negative; } \\
\text { pleural fluid } \\
\text { AFB culture } \\
\text { positive for } \\
\text { Mycobacterium } \\
\text { tuberculosis } \\
\text { complex }\end{array}$ & + & $\begin{array}{l}\text { Symptoms } \\
\text { resolved with } \\
\text { interval } \\
\text { improvement of } \\
\text { CXR }\end{array}$ \\
\hline \multicolumn{9}{|c|}{$\begin{array}{l}\text { *ADA, adenosine deaminase; AFB, acid-fast ba } \\
\text { interferon gamma release assay; NA, not appli } \\
\text { positive. } \\
\text { †These patients reside in the same dormitory. }\end{array}$} \\
\hline
\end{tabular}

the 4 patients' pulmonary radiologic findings were more consistent with those for TB, highlighting the value of considering other pulmonary pathologic conditions for patients with COVID-19.

Risk factors for TB include low socioeconomic status and overcrowded living conditions (4). Of note, patients 1 and 3 resided in the same dormitory. Migrant worker dormitories are often inadequately ventilated and crowded, resulting in residents being more susceptible to infectious diseases, including dengue, Zika, and varicella $(5,6)$. The same working and living conditions have served
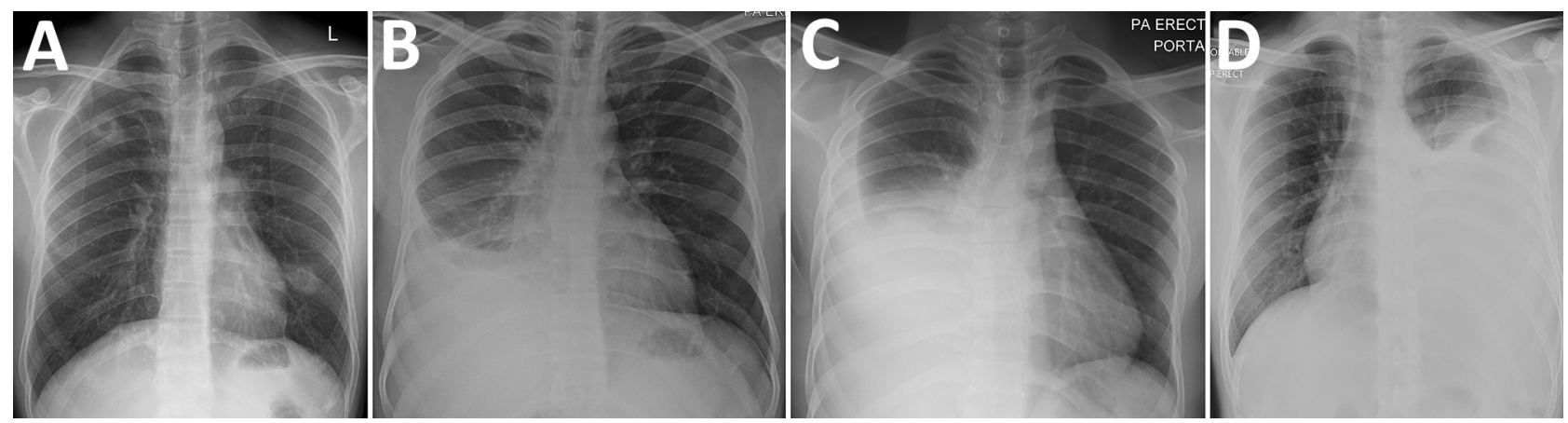

Figure. Plain chest radiographs of 4 patients with severe acute respiratory syndrome coronavirus 2 and Mycobacterium tuberculosis co-infection, Singapore. A) Patient 1, showing bilateral cavitary lesions; B) patient 2, showing a large right-sided loculated pleural effusion and adjacent consolidation; C) patient 3, showing a large right-sided pleural effusion with adjacent compressive atelectasis; D) patient 4, showing a large left-sided pleural effusion with adjacent consolidation. 
as a catalyst for the rapid transmission of SARS$\mathrm{CoV}-2$, and potentially $\mathrm{TB}$, in this population. Improving screening processes and living conditions and implementing routine vaccination strategies for this population may prevent future infectious disease outbreaks.

As the COVID-19 pandemic continues, care for patients with TB may be compromised as additional strains are placed on essential services. The 4 cases we report highlight a serious public health issue. Precautionary measures must be undertaken to be vigilant of an epidemic within the ongoing pandemic-TB. To ensure that care is not compromised, clinicians treating these at-risk populations should be aware of possible co-infection with $M$. tuberculosis and SARS$\mathrm{CoV}-2$ in patients with atypical radiographic features of COVID-19.

\section{About the Author}

Dr. Tham is an infectious diseases senior resident in the Department of Medicine at the National University Hospital of Singapore. His research interests include virology and public health.

\section{References}

1. Ministry of Health Singapore. COVID-19 situation report [cited 2020 Jun 29]. https:/ / covidsitrep.moh.gov.sg

2. Ministry of Health Singapore. Communicable diseases surveillance in Singapore [cited 2020 May 15].

https://www.moh.gov.sg/docs/librariesprovider5/ diseases-updates/communicable-diseases-surveillance-insingapore-2018210c9a3beaa94db49299c2da53322dce.pdf

3. Shi H, Han X, Jiang N, Cao Y, Alwalid O, Gu J, et al. Radiological findings from 81 patients with COVID-19 pneumonia in Wuhan, China: a descriptive study. Lancet Infect Dis. 2020;20:425-34. https:/ / doi.org/10.1016/ S1473-3099(20)30086-4

4. Narasimhan P, Wood J, Macintyre CR, Mathai D. Risk factors for tuberculosis. Pulm Med. 2013;2013:828939. https:/ / doi.org/10.1155/2013/828939

5. Sadarangani SP, Lim PL, Vasoo S. Infectious diseases and migrant worker health in Singapore: a receiving country's perspective. J Travel Med. 2017;24:1-9. https://doi.org/10.1093/jtm/tax014

6. Ho ZJM, Hapuarachchi HC, Barkham T, Chow A, Ng LC, Lee JMV, et al.; Singapore Zika Study Group. Outbreak of Zika virus infection in Singapore: an epidemiological, entomological, virological, and clinical analysis. Lancet Infect Dis. 2017;17:813-21. https://doi.org/10.1016/ S1473-3099(17)30249-9

Address for correspondence: Gabriel Yan, Division of Infectious Diseases, Department of Medicine, National University Health System, NUHS Tower Block, 1E Kent Ridge Rd, 119228,

Singapore; email: gabriel_zherong_yan@nuhs.edu.sg

\section{Seroprevalence of SARS-CoV-2 and Infection Fatality Ratio, Orleans and Jefferson Parishes, Louisiana, USA, May 2020}

\author{
Amy K. Feehan, Daniel Fort, Julia Garcia-Diaz, \\ Eboni G. Price-Haywood, Cruz Velasco, Eric Sapp, \\ Dawn Pevey, Leonardo Seoane
}

Author affiliations: Ochsner Clinic Foundation, New Orleans,

Louisiana, USA (A.K. Feehan, D. Fort, J. Garcia-Diaz,

E.G. Price-Haywood, C. Velasco, D. Pevey, L. Seoane);

University of Queensland Ochsner Clinical School, New Orleans

(A.K. Feehan, J. Garcia-Diaz, E.G. Price-Haywood, L. Seoane);

Public Democracy, Arlington, Virginia, USA (E. Sapp); Louisiana

State University Health Science Center-Shreveport, Shreveport,

Louisiana, USA (L. Seoane)

DOI: https://doi.org/10.3201/eid2611.203029

Using a novel recruitment method and paired molecular and antibody testing for severe acute respiratory syndrome coronavirus 2 infection, we determined seroprevalence in a racially diverse municipality in Louisiana, USA. Infections were highly variable by ZIP code and differed by race/ethnicity. Overall census-weighted seroprevalence was $6.9 \%$, and the calculated infection fatality ratio was $1.63 \%$.

Seroprevalence studies around the world have Sestimated the spread of severe acute respiratory syndrome coronavirus 2 (SARS-CoV-2) to range from $1.79 \%$ (1) in Boise, Idaho, USA, to $25 \%$ in Breves, Brazil (P. Hallal, unpub. data, https:// doi.org/10.1101/2020.05.30.20117531). Coronavirus disease (COVID-19) has also been reported to disproportionately affect Black patients, but we do not know the infection fatality ratio (IFR), which requires knowing how many persons are at risk (i.e., infected). We estimated SARS-CoV-2 infections in Orleans and Jefferson Parishes, Louisiana, USA, and determined the COVID-19-related IFR by race.

The protocol was approved by the Ochsner Clinic Foundation Institutional Review Board (New Orleans, LA, USA) and designed to enroll and test up to 3,000 persons at 10 sites during May 9-15, 2020. To recruit a representative sample for this high-throughput method, a novel 2-step system developed by Public Democracy (https://www.publicdemocracy. io) considered $>50$ characteristics, including social determinants of health and US Census population 